\title{
When Is a Fish Not a Fish? Questions Raised by a Nage Life-Form Category
}

\author{
Gregory Forth
}

Author Address: 13-15 HM Tory University of Alberta Edmonton, Alberta Canada T6G 2H4 gforth@ualberta.ca

Received: January 20, 2012

Volume 3:23-30

Published: June 12, 2012

(C) 2012 Society of Ethnobiology

\begin{abstract}
Speakers of a Central-Malayo-Polynesian language, the Nage inhabit the central region of the eastern Indonesian island of Flores. Their folk taxonomy of animals (ana wa) contains three named life-form taxa, one of which is ika, fish. A review of component folk-generic taxa, however, reveals that Nage do not classify five kinds of freshwater fish as 'fish' (ika), even though they further apply ika to various marine fish (including sharks and rays) as well as to marine mammals. The article considers this peculiarity of Nage folk zoological taxonomy, and how it might affect an understanding of ika as denoting a 'fish' life-form taxon. The main conclusion is that the five excluded categories-distinguished largely on morphological and behavioural grounds, and conveniently designated as the 'tebhu cluster', after one of their members-are contrasted primarily with freshwater species which Nage do classify as 'fish' (ika). Specified by name as ika lowo ('river fish'), these are further contrasted with another named folk-intermediate taxon of 'marine fish' (ika mesi). From this, it is argued that, as a life-form category, ika should be understood as implicitly including the five members of the 'tebhu cluster' as a third, albeit covert, folk-intermediate taxon.
\end{abstract}

Key words: life-forms, fish, marine fish, freshwater fish, Nage, folk taxonomy

\section{Introduction}

The theory of 'life-forms' is well established in ethnobiology. In regard to animals, it is widely accepted that people the world over distinguish large, general classes of creatures coinciding with English vernacular 'bird', 'snake', and the like, which further reveal some coincidence with scientific taxa, such as classes, orders, and sub-orders. Life-forms (such as 'bird') may be 'covert', which is to say unnamed. But evidence for these folk taxa is obviously clearest when they are named, and moreover named with single lexemes (German 'vogel', translating as English 'bird', provides a good example). As Brown (1984) has demonstrated, languages vary in the number of life-form taxa they name, and such named taxa occur in a relatively fixed order. Thus, where there is just one term, this will be 'fish', 'snake', or 'bird'; where there are two, they will be two of these three; and where there are three, they will, almost without exception, be precisely these three. Also, when there are four or five life-form terms, 'fish', 'snake', and 'bird' will be retained, so to speak, while terms for 'mammal' and 'wug' (a term coined to describe folk categories mostly comprising small invertebrates) will be added to this more basic triad. In this respect, it may be noted, Brown's thesis is essentially similar to the 'evolutionary' approach proposed with reference to colour terminology by Berlin and Kay (1969).

Among the most basic of named life-form taxaor employing the evolutionary idiom, the 'earliest' to be named-are 'fish' and 'snake'. The Nage of Flores Island, eastern Indonesian cultivators and hunters whose folk classification of animals is the subject of the present discussion, name just three life-forms. Two of these, 'snake' (nipa) and 'fish' (ika) are designated with single lexemes, while 'bird' is normally labeled by the descriptive phrase ana wa ta'a co, meaning 'animals that fly'. Closer attention to the content of the classes, however, reveals peculiarities of the 'fish' category. Nage ika includes a variety of marine and riverine creatures, all of which typically fall within a 'fish' lifeform in other ethnozoological taxonomies, yet it excludes a number of freshwater species which vernacular English speakers would classify as fish and which fall under the rubric of 'fish' as commonly employed in scientific discourse. ${ }^{1}$ In other words, the Nage appear to consider a number of fish as non-fish. It might therefore be asked whether ika can in fact be 
fully comprehended as a life-form taxon, as opposed to a smaller, more exclusive grouping, or whether Nage ethnotaxonomy is more accurately characterized as incorporating two life-forms that apply to 'fish'. As this may suggest, the case also draws attention to features of the concept of life-form in general.

\section{Ethnographic Details and Formal Particulars}

Residing in central Flores just north of the Ebu Lobo volcano, Nage are a highland people. As such, their experience of fish is limited to several riverine species and, nowadays, fish sold, either fresh or dried, in weekly markets. During the last decade, in more developed settlements, fresh fish have become available for purchase on a daily basis, from young men who travel by motorbike outside the Nage region to the port settlement of Ende, each morning bringing back fish in large plastic containers. In central Nage, the main focus of my ethnographic research, ${ }^{2}$ fish have thus become an important part of daily diets, and being consumed in significantly greater quantities than fowl or meat, they are now a major source of protein. By contrast, in former times, fish and other freshwater creatures, caught with hooks and lines, nets, traps, and stone weirs, were of far less dietary importance. It is also noteworthy that, apart from the Ae Sésa, central Flores' major river located to the north of central Nage territory, water courses containing fish are restricted to small rivers and streams, and that, while people do still fish, bodies of freshwater suitable for fishing are somewhat more restricted than they were in the early twentieth century, owing to alterations to water courses to facilitate wet-rice cultivation, introduced during the colonial era.

Like Indonesian (or Malay) ikan and in fact words for 'fish' in most Malayo-Polynesian languages and two Formosan languages, Nage ika (fish) reflects ProtoAustronesian * Sikan (Blust 2002:125; cf. Zorc 1994:545, 591, who notes that the prototerm literally means 'what is used for eating', thus 'food'). As shown in Table 1, ika comprises two sub-categories which, following Berlin's scheme, can be construed as 'folkintermediate' taxa. One is 'sea fish', a category that comprises fish not further distinguished by individual Nage names but which are known simply as $\mathbf{i k a}$ or ika mesi (mesi is 'salty; saltwater, the sea'). Nowadays fish of this sort, mostly encountered as dead specimens for sale, are distinguished by Indonesian names, for example, ikan tonggkol, 'tunny fish'. Also included among 'sea fish' are creatures that, according to international zoology, are not fish, in particular marine mammals. At least one marine fish which is not classified as a fish (ika, ika mesi) is $\mathbf{i p u}$, the immature form of a fish species which enters estuaries during certain months of the year, where coastal dwellers catch them in large numbers.

The other sub-category of ika is ika lowo ('river fish'). Of these, central Nage nominally distinguish four folk-generic taxa as indigenous kinds (see Table 1, Section 1a). However, informants consistently describe all of these as having disappeared from local rivers and streams. Nage attribute this disappearance to the construction of the irrigation dam in Mbai, just upstream of the estuary of the Ae Sésa river, in the 1960s. They further remark how some returned temporarily following a breach of the Mbai dam sometime in the 1970s or 1980s. All kinds of ika lowo (river fish), therefore, are evidently species that spend part of the life cycle in saltwater. All water courses in the Nage region, it should be noted, ultimately flow northwards and empty into the Ae Sésa upstream of the dam.

This ecological change would seem to explain statements I occasionally recorded to the effect that all animals Nage classify as ika (fish) are sea fish. At the same time, there are several species of freshwater fish which have been introduced to central Flores during the twentieth century, some for farming in paddy-fields which have subsequently escaped into local rivers. There are three or possibly four kinds of these, and all are known only by their names in the Indonesian national language (see Table 1 Section $1 \mathrm{~b}$ ); hence it is commonly claimed that, nowadays, all ika lowo (or freshwater fish) are introduced varieties.

Definitely excluded from the category ika are five folk-generic taxa comprising several species of freshwater fish (see Table 1, section 3). For reasons I explain below, these can be collectively designated as the 'tebhu cluster'. Although I have not been able to confirm species identifications for the several Nage categories, from questioning with photographs and illustrations stored on a lap-top computer and from detailed informant descriptions, the majority appear to be members of the Gobiidae. Because all five are creatures that are classified as ikan ('fish') in Indonesian, the national language in which almost all Nage are nowadays fluent, the consistency with which Nage characterize the five kinds as not belonging to the category ika is remarkable. Nage, moreover, can readily articulate reasons why they do not classify them as $\mathbf{i k a}$. Ika, they say, have thin (that is, elliptical) bodies covered in scales, with the height far exceeding the width. They also swim freely at mid-depth or near the surface of the water, and they travel in groups. By 
contrast, the five kinds composing the tebhu cluster, Nage point out, have round bodies with scales only on the head or the front part of the body, and they are always found on or near the bottom of streams or pools, either adhering to rocks or burying themselves in sand. Finally, whereas ika swim freely and are generally active, members of the tebhu group are described as moving only in order to feed and, unlike fish classified as $\mathbf{i k a}$, as swimming separately rather than in shoals.

Curiously, these criteria would appear to exclude introduced scaleless and round-bodied catfish (ikan léle or ika léle) from the category of ika. However, I suspect that, insofar as Nage do count of these as ika, the usage reflects the national language specification of these fish as a kind of ikan. The fact that catfish have a recognized external origin also accords with the classification of a variety of marine creatures as ika, these of course being similarly alien to Nage highlanders. Although Nage have no collective name for the five members of the tebhu cluster, by virtue of the common morphological and behavioural features just described they clearly recognize them as a group and regularly mention them together in free recall listing of freshwater creatures. An especially close relationship between two kinds is revealed by the names ana tebhu and tebhu teke, 'Gecko tebhu' (see Table 1, Section 3). Since ana (contextually meaning 'animal, member, instance of a kind') is an optional component of many Nage animal names, tebhu can be understood as a short form of ana tebhu; hence tebhu teke could be regarded as a sub-category of tebhu (meaning ana tebhu). Nage explicitly compare other members of the cluster ana tebhu. Ana tebhu are described as possessing discs or suckers and attaching themselves to rocks in streambeds; so too are kaka watu, whose name 'attaches, holds on to stones' explicitly refers to this behaviour. One man also described kaka watu as climbing on to rocks after leaving the water, thus suggesting a mudskipper, although mudskippers are not clearly attested on Flores (Monk et al. 1997). Employing a formulation typical of Nage taxonomic discourse, one of my most knowledgeable and articulate sources on Nage folk zoology stated that there are "three kinds of ana tebhu: tebhu teke, kaka watu, and ana tebhu." ${ }_{3}$ Another informant specified the fish called pusu as "a kind of ana tebhu" (bhia ko'o ana tebhu), an expression which however commonly refers to resemblance rather than class inclusion. I seem not to have recorded a similar statement regarding su lai, but as evidenced by its name, 'sand penetrator', this fish remains at the bottom of streambeds and to that extent exhibits behaviour characteristic of all members of the group.

As a covert category, the tebhu cluster evidently has its focus in ana tebhu, probably a member of the genus Sicyopterus, and the folk-generic to which other members of the unnamed grouping are regularly compared. Another indication of this focal status is the standard compound kuza tebhu, 'prawns and tebhu fish', a utilitarian category that refers generally to edible creatures found in fresh water. Thus compounded, tebhu therefore implicitly includes other fish besides the one designated ana tebhu, although of course the term, or the entire expression, encompasses much else besides. In the same context, kuza tebhu is synonymous with the more common utilitarian compound kuza tuna, prawns and eels (see also kogha wawi, kuza tuna [deer and pigs, prawns and eels], an expression denoting all wild foods deriving from land and freshwater, and even all food deemed fit for human consumption). Interestingly, among utilitarian categories ika (fish) appears only to occur in ika kima (fish and shellfish), a reference to foods derived from the sea. In this context the term obviously refers specifically to marine fish-a circumstance consistent with the modern situation where, apart from freshwater exotics, the only fish classified as ika that are consumed by Nage are marine fish.

As indicated in Table 1 (Section 4), eels (tuna) formally resemble members of the tebhu cluster insofar as they too are not considered ika (fish). Eels are of course classified as fish in English scientific discourse, and they can also be counted as ikan (fish) in Indonesian. In Anglophone folk zoology, however, 'fish' and 'eel' are usually treated as a simple contrast, which is to say most Anglophones would not regard eels as a kind of fish. In this comparison, the Nage exclusion of ana tebhu and related folk-generics from the category labelled ika may appear less peculiar; yet possible reasons for the Nage contrast still require discussion.

As all members of the tebhu cluster are eaten, as are all $\mathbf{i k a}$, the distinction has no relation to edibility. It is also largely devoid of ritual or cosmological import. The one possible exception concerns the spiritual beings Nage call nitu. When encountered in animal guises these spirits mostly take the form of snakes, but they can also appear as freshwater fish, eels, and crustaceans. Their identification as fish applies largely to traditional narratives, where they are specified simply as ika (fish); accordingly, in response to my question, I was told that nitu never take the form of ana tebhu or other creatures belonging to the tebhu cluster. The 
Nage characterization of members of this group as being only partly covered in scales is interesting in relation to the abominations of Leviticus (11:12; cf. Deuteronomy 14:10), wherein "whatsoever hath no fins nor scales in the waters" is deemed unclean and is therefore prohibited. Also, the fact that they occur on the bottom of streambeds and do not swim freely in clear water is reminiscent of the Biblical abomination of creeping or crawling creatures. But whereas the Old Testament taboos define which animals can and cannot be eaten or otherwise used, the Nage distinction has no such significance, and in fact the taxonomic contrast, founded on features of morphology and behaviour, lacks virtually any symbolic or utilitarian dimension.

The Nage restriction of ika to certain kinds of freshwater fish, and their explicit exclusion of several other kinds, is remarkable not only in relation to the extension of ika to a wide variety of marine creatures (including sharks, rays, and sea mammals) but also in comparison with the extension of Indonesian/Malay ikan. The Indonesian cognate can occur in compounds denoting eels (ikan belut), squid and cuttlefish (ikan cumi-cumi, ikan sotong), dugong (ikan duyung), sharks (ikan hiu), dolphins (ikan lumba-lumba), rays (ikan pari), whales (ikan paus, ikan lodan), and jellyfish (ikan ubur-ubur) — that is, a large variety of fish and non-fish, vertebrates and invertebrates, as well as numerous other kinds of freshwater and saltwater fish (Stevens and Schmidgall-Tellings 2004). In fact, several Nage compound names for 'sea fish' may reflect the influence of Malay or the Malay-based national language. Examples include ika pau (Malay ikan paus), ika duyu (ikan duyung), ika pai (ikan pari), and ika iu (ikan hiu). The only Nage folkgeneric denoting a marine creature classified as ika which does not obviously conform to this pattern is lobhu, 'dolphin' (cf. Malay lumba-lumba), in part because the name is never in my experience prefixed by ika. On the other hand, the broad application of ika to marine species cannot simply be ascribed to the influence of Malay, for one could then reasonably expect the same to apply to the several freshwater fish which Nage insist are not ika. It might be hypothesized that names of such 'sea fish' (ika mesi) as, for example, ika duyu (dugong) and ika méze (whale, or 'great fish') are non-productive compounds, that is, essentially metaphorical usages which are to be understood as denoting 'real' fish no more than does the English name 'silverfish' (designating a small silvercoloured invertebrate). The suggestion is however purely speculative; it is not definitively borne out by Nage statements and would be difficult to subject to further test. A better explanation for the comprehensive character of the category ika mesi may be found in the ecological circumstance that, traditionally and still largely at present, highland Nage are unfamiliar with creatures like Cetaceans (whales and dolphins) and Sirenians (dugongs), as well as sharks and rays, knowing only that these all possess the same general shape as freshwater fish and live in the sea. It may even be speculated that ika has been adopted as something of a provisional label for these unfamiliar creatures which, moreover, Nage rarely need to identify, name, or classify in any case. At the same time, this interpretation may not be essentially different from the interpretation of ika méze ('great fish', whale), for example, as an unproductive compound.

\section{Analysis and Conclusion}

Ika qualifies as a life-form taxon since it includes a wide variety of folk-generics of the same general form. The category also subsumes two named folkintermediate taxa (ika lowo and ika mesi), and like other life-forms it possesses a focal structure. Nowadays the most focal of fish-those kinds considered the 'best examples' of ika and which are mostly likely to be mentioned first in free-recall-are probably sea fish regularly encountered in modern markets. Before the early part of the 20th century, and thus before the establishment of markets, saltwater fish were rarely encountered by Nage highlanders; also, prior to the last few decades, such fish were mostly available as dried filets, not as complete specimens. Traditionally, therefore, the most typical ika were almost certainly ika lowo, the grouping of four categories incorporating ika in their names which are no longer present in Nage inland waters owing to the Mbai dam.

No explanation is available for the Nage exclusion of five folk-generics of freshwater fish from the taxon ika. The separation appears curious especially in view of the inclusion in ika of sea fish and other marine animals, particularly as many of the latter are, according to Nage folk zoologists' own criteria-elliptical shape, scales, swimming in shoals at mid-depth or close to the surface_-even less like ika lowo (river fish) than are ana tebhu and other excluded members of what I call the 'tebhu cluster'. By the same token, it is evident that exclusion of the tebhu cluster from ika is contextual, relating specifically to perceptible contrasts among species of freshwater fish. As noted, Nage are explicit, even insistent, that these five kinds are not 'fish' (ika). In this, one may be tempted to suggest that they "protest too much," and that the contrast they 
articulate between $\mathbf{i k a}$ and the tebhu group is best understood as a hyperbolic way of emphasizing a suite of morphological and behavioural differences. Yet, quite apart from the fact that it is always risky to second guess one's informants, the distinction holds little if any practical importance for Nage; thus, hyperbolic or otherwise, its motivation remains unclear.

Based on explicit morphological and behavioural traits, the contextual character of the contrast of ika and the tebhu cluster, applying specifically to a particular level of Nage animal taxonomy, raises other possibilities. In fact, this specificity strongly suggests that the five non-ika are perceived as distinct not so much from ika as an entire life-form as from the taxon specified as ika lowo (river fish). This in turn allows for the implicit inclusion of the tebhu cluster in ika in the broader sense- even though Nage speak simply of ika as the category with which the cluster contrasts. The tebhu grouping would then together compose an unnamed folk-intermediate taxon forming part of the life-form ika.

Since the five folk-generics are implicitly recognized as a group, showing a variety of common features and not simply composing a negative category in opposition to ika lowo (river fish), they cannot be treated as a congeries of unaffiliated folk-generics. One alternative might be to consider them as a covert lifeform contrasting with 'fish' in general, that is, ika subsuming both ika lowo and ika mesi (thus also sharks, whales, dugongs, and so on). But as we have seen, the contrast for Nage evidently pertains only to the first of these two taxa. ${ }^{4}$ There is just one other formal possibility, namely to regard the tebhu cluster as an unaffiliated covert folk-intermediate, that is, an unnamed category comprised of several named folkgeneric categories which is not itself subsumed by any more inclusive category except, of course, the Nage 'unique-beginner' taxon animal or creature (ana wa). This, however, requires viewing the tebhu cluster as a group of creatures that Nage regard as fundamentally distinct from all fish (ika), and this is not supported by the evidence. In addition, although 'folk-intermediate' obviously has a relative sense, it raises the formal question of whether the analytical concept can usefully be applied to a category that does not form part of any life-form. ${ }^{5}$

Revealing obvious differences between Nage classification of fish, scientific taxonomy, and vernacular classifications found in English, Bahasa Indonesia (Malay), and other languages, the present case might seem to call aspects of the 'life-form' concept into question and even raise doubts about the intellectualist or universalist theory of ethnobiological classification as a whole. To reject the theory categorically, however, would be to throw the proverbial baby out with the bath water-or, perhaps more appropriately in this instance, the fish with the pond water. As with animals of other kinds, fish are classified in Nage folk taxonomy primarily on morphological and behavioural grounds and by a principle of inclusion effecting a hierarchy of four levels: animal (ana wa) - fish (ika) - e.g. river fish (ika lowo)—and e.g. ika hepa (see Table 1). As this specification shows, 'life-form' figures as an essential component of the scheme, and even if ika does not subsume the tebhu cluster, this circumstance does not compromise the status of $\mathbf{i k a}$ as a life-form category.

To this extent, Nage classification can be seen to conform to a pattern grounded in a pan-human cognition based on perception of natural discontinuity. But this is a pattern best understood not as a rigid template, but as a set of basic principles that allows for variation in different ethno-linguistic environments. Indeed, Nage ichthyological taxonomy exemplifies such variation with especially clarity, revealing what is evidently a particular cultural shaping of a fundamentally universal scheme. On the one hand, ika is maintained as a named life-form category. On the other, a specifically Nage classification has, as it were, subtracted from this a series of folk-generics that would very likely be included in a 'fish' life-form in other cultural and linguistic settings.

My basic conclusion, that the $\boldsymbol{t} \boldsymbol{e b h} \boldsymbol{u}$ cluster should be understood as a covert folk-intermediate within the life-form ika, might seem to support suggestions that folk-intermediates are specifically cultural categories (Brown 1974, Atran 1983). Yet what specific cultural factors could account for this feature of Nage fish taxonomy remains undetermined. Despite the location of the contrast of ika (=ika lowo) and the tebhu cluster at the level of folk-intermediate taxa, it might just be considered that a new utilitarian value on freshly caught saltwater fish, now almost challenging meat as a preferred food, has influenced the distinction Nage make between two different forms of freshwater fish. But there is no evidence that this value is the origin of the distinction, while other evidence suggests that the contrast is much older than the hypothesis would require.

\section{References Cited}

Arndt, P. 1961. Wörterbuch der Ngadhasprache. Studia Instituti Anthropos, 15. Anthropos-Institut, Posieux, Fribourg, Suisse. 
Atran, S. 1983. Covert Fragmenta and the Origin of the Biological Family. Man 18:51-71.

Berlin, B. 1992. Ethnobiological Classification: Principles of Categorization of Plants and Animals in Traditional Societies. Princeton University Press, Princeton, NJ.

Berlin, B. and P. Kay. 1969. Basic Color Terms: Their Universality and Evolution. University of California Press, Berkeley.

Blust, R. 2002. The History of Faunal Terms in Austronesian Languages. Oceanic Linguistics 41:89-139.

Brown, C. H. 1974. Unique Beginners and Covert Categories in Folk Biological Taxonomies. American Anthropologist 76:325-27.

Brown, C.H. 1984. Language and Living Things: Uniformities in Folk Classification and Naming. Rutgers University Press, New Brunswick, NJ.

Forth, G.. n.d. Nage Lizard Classification: Free-Listing and Other Evidence for a Covert Life-Form. To appear in Anthropological Linguistics.
Monk, K., Y. de Fretes, and G.Reksodiharjo-Lilley. 1997. The Ecology of Nusa Tenggara and Maluku. Periplus Editions, Hong Kong.

Stevens, A. M. and A. Ed. Schmidgall-Tellings. 2004. A Comprehensive Indonesian-English Dictionary. Ohio University Press, Columbus.

Zorc, R. D. P. 1994. Austronesian Culture History through Reconstructed Vocabulary (an Overview). In Austronesian Terminologies: Continuity and Change (Pacific Linguistics Series (-127), edited by A.K. Pawley and M.D. Ross, pp. 541-594. Department of Linguistics, Research School of Pacific and Asian Studies, The Australian National University, Canberra.

\section{Biosketch}

Gregory Forth is a social/cultural anthropologist and ethnozoologist. His most recent book is Images of the Wildman in Southeast Asia (2008).

Table 1: Nage Names of Fish (Ika) with Descriptive Notes

Ika Lowo (River Fish) or Ika Ae ([Fresh] Water Fish)

\section{Native Kinds}

Ika wonga huma

Huma flower fish; huma is a tree whose white blossoms the fish's colour resembles; unidentified

\section{(Ika) hepa}

Broom fish; possibly so named because the fish can grow as long as a hand broom (hepa); some evidence suggests ika hepa may be the most focal member of this group; unidentified

\section{(Ika) izu nguza}

'Nose, snout fish'; (izu (nose); nguza can mean 'sprout' or 'young, newly emerged'; so called because it sticks its snout about the water; unidentified

Ika léro (or leo)

Léro fish; so named because of its yellowish markings resembling the skin pattern of the Timorese python (Python timoriensis Peters Pythonidae), called goka leo; unidentified

In some Flores languages léro is 'yellow'; also the /r/ commonly included in the name suggests a possible external derivation since / $\mathrm{r} /$ has disappeared from several Nage dialects.) In central Nage leo denotes the Black-naped oriole (Oriolus chinensis L. Oriolidae).

\section{Exotic Kinds}

Introduced in the 20th century and known only by Indonesian (Malay) names (identifications from Stevens and Schmidgall-Tellings 2004) 
Ikan léle (or ika léle)

Kind of catfish, Clerius melanoderm

Ikan mas

Goldfish, kind of carp, Cyprinus carpio L. Cyprinidae

Ikan mujair

Tilapia, a freshwater fish, Tilapia mossambica Peters Chichlidae

Ikan nila

Unidentified (mentioned by one informant only)

Ika Mesi (Sea Fish) or Ika Lau (Seaward Fish)

Ika or ika mesi

Various species of marine bony fishes (Osteichthyes), for example, the tunny or bluefin tuna (Thynnus

thunnina Cuvier Carangidae), in Indonesian called ikan tongkol; there are no Nage names for individual kinds

of sea fish, and Nage distinguish these only with Indonesian names

Duyu or ika duyu

Dugong, Dugong dugon Muller Dugongidae

Ika méze

Whales (literally 'big fish'), also called ika pau (from Indonesian ikan paus, 'whale')

Iu or ika iu

Sharks

Ika pai (or pari)

Rays

Lobhu

Dolphin (Delphinidae); probably referring most often to Peponocephala electra Gray Delphinidae, melon-headed dolphin, or Stenella coeruleoalba Meyen Delphinidae, striped dolphin (Monk et al. 1997:462)

\section{Tebhu Cluster}

Ana tebhu

Probably Sicyopterus sp.

\section{Tebhu teke}

Also Sicyopterus; described as resembling ana tebhu but distinguished by a head shaped like that of the Tockay gecko (Gekeko gecko L. Gekkonidae), teke

Kaka watu or kebhi watu

Probably Stenogobius sp.; described as attaching itself to rocks at the bottom of streams (kaka and kabhi both mean 'to attach, adhere'; watu is 'rock' or 'stone'

Pusu

Pusu also means 'heart'; described as larger than ana tebhu and as also resembling a catfish (ikan léle); unidentified

Su lai

So named because it lives in sandy stream beds; $\boldsymbol{s u}$, means 'to penetrate, enter'; lai is 'sand'; unidentified 
Other Aquatic Creatures not Identified as Ika (Fish)

Tuna

Eels; three or four kinds are distinguished

Kuza

Crustaceans, especially freshwater prawns, crayfish; nominally distinguished into four or more varieties

Ana fe

Tadpoles, generally recognized as creatures which transform (bale) into frogs (pake)

Kea, kea mesi

Marine turtles

Ipu

Fry, immature form of fish which in certain months enter estuaries from the sea where they are caught in large numbers by coastal dwellers

Podhe

Possibly an immature prawn (cf. Arndt 1961); known to most Nage only as an unidentified sea creature which characteristically enters estuaries in advance of $\mathbf{i p u}$

${ }^{1}$ In scientific zoology 'fish' is a notably various category and for that reason may be judged not particularly 'scientific'. It covers two scientific classes: Osteichthyes (bony fish), sometimes treated as a superclass, and Chondrichthyes (cartilaginous fish, including sharks, rays, and skates). Comprising lampreys and hagfish, a third group is the Agnatha, or 'jawless fish', now recognized as a superclass and sometimes not considered true fish. By contrast, 'bird' and 'mammal', for example, respectively coincide with two scientific classes (Aves and Mammalia).

2 By 'central Nage' I refer to the inhabitants of the three original 'Nage desa' (administrative 'villages' or municipalities) centered on the colonial capital village of Bo'a Wae.

3 An additional category may be ana $\boldsymbol{b o}$. However, while sometimes described as a creature morphologically similar to but smaller than ana tebhu, other information suggests the term may be a dialectal name for the fish central Nage call ana tebhu. In his dictionary of the neighbouring Ngadha language, Arndt (1961:198 s.v. cana [=ana]) gives cana bo and cana bebu as 'small river fish'.

${ }^{4}$ In regard to internal resemblance, and indeed the number of component generics, the $\boldsymbol{t} \boldsymbol{e b h} \boldsymbol{u}$ cluster recalls the five lizard taxa named by Nage. Elsewhere (Forth n.d.) I have argued that these do indeed compose an unnamed life-form. However, crucial to this determination is evidence for Nage recognition of 'lizard' not only as a distinct grouping of animals but as one represented as contrasting with 'snake' (nipa), one of the named Nage life-forms.

5 This analysis may raise questions about other areas of Nage classification of aquatic creatures, especially eels (tuna) and crustaceans (kuza). Although the matter cannot be properly treated here, both tuna and kuza are best understood as unaffiliated folk-generics, each further divided into a number of 'folk-specifics' (sensu Berlin 1992). In response to free-listing of freshwater creatures, tuna and kuza are accordingly mentioned, without further specification, along with the folk-generics listed in Table 1. 